\title{
The Ethiopian famine
}

\section{By D. S. Miller and J. F. J. Holt, Queen Elizabeth College, Campden Hill, London $W 8{ }_{7} A H$}

It has been suggested that the Ethiopian famine is only one facet of a long-term climatic change whose effects include the southward movement of the Sahara. The impression is often given that famine is widespread across a belt of Africa from Cape Verde to the Red Sea, but nothing could be further from the truth. Famine is defined as an extreme shortage of food, but this must be viewed in relation to customary food intakes, which, although often low, are able to sustain an increasing population. Extreme starvation is certainly not typical of the Sahel, although it has occurred in localized areas in Mauritania, Mali, Niger and Chad. Equally untrue is the impression created by the media that there was widespread famine in Ethiopia. Indeed we shall present some information to indicate that food production for the country as a whole was not low at the critical time. Perhaps a more apt title for this paper would be the famine in Wollo, a province of about 2.5 million people, but not all of them were affected.

It is customary to distinguish between chronic undernutrition and famine. The former is journalistically dull, and very little has been achieved to alleviate the problem. Political measures are required to deal with such sensitive areas as land tenure, the capital demands of rural development, the easy money to be made from an urban light industry surrounded by cheap labour, and general corruption in the cities of the developing world. Famine, on the other hand, attracts much publicity and creates an entree for foreign agencies to work in areas previously prohibited or ignored, but action is limited to treating symptoms rather than causes. In fact, of course, famine is merely the 'tip of an iceberg' and indicates widespread chronic undernutrition. In so far as the distinction is necessary, it might be more profitable if the charities concerned in famine relief would concentrate on feeding hungry people rather than attempting to treat the nutritional deficiencies and endemic diseases that prevailed before the famine started. Sophisticated medical teams providing expensive pharmaceutical preparations, such as protein hydrolysates and vitamin pills, must be regarded as a dissipation of limited funds (Rivers, Seaman \& Holt, 1974). It seems self-evident that the primary need of starving people is food. It is also clear that an evaluation of the effects of a famine should be on the basis of a comparison against what existed before, rather than against our own high European standards.

In Ethiopia we were fortunate in having completed a nutritional study in a northern agricultural area over a 4-year period immediately before 1973, the year of the famine. We were aware of a moderate migration of people from the rural areas to the roadside towns and on to the capital cities, a characteristic that was 
accentuated during the famine. The project took the form of an experimental evaluation of an applied nutrition programme with a suitable control. Energy intakes were calculated from weighed $3 \mathrm{~d}$ individual food intakes of thirty-six subjects on six separate occasions. The mortality data were individually recorded for a population of 2770 over a period of 3 years. The energy intakes shown in Table $\mathrm{I}(\mathrm{a})$ indicate an extremely low nutritional status and this was exacerbated by a deficiency of vitamin A and by goitre. Not surprisingly the body-fat reserves of the population, as indicated by skinfold thickness, were also very low. The heights and body-weights of the people show the chief adaptation to undernutrition, and superficially these small people appeared in good health. However, morbidity data collected at our clinic showed a high prevalence of gastroenteritis, intestinal parasites, venereal diseases, and some malaria.

Table I. Nutritional and mortality indices of Ethiopians recorded before the 1973 famine

(a) Nutritional indices

\begin{tabular}{|c|c|c|c|c|c|c|c|c|c|}
\hline & & (Mea & alues with $t$ & ir standa & err & & & & \\
\hline & & $\begin{array}{l}\text { Energ } \\
\text { (MJ(1) }\end{array}$ & $\begin{array}{l}\text { take } \\
/ / d \text { ) }\end{array}$ & $\begin{array}{l}\text { Tric } \\
\text { skinfold }\end{array}$ & & $\begin{array}{r}\text { Bod } \\
\text { weight }\end{array}$ & & $\begin{array}{l}\text { Heig } \\
\text { (m }\end{array}$ & \\
\hline & & ean & SE & Mean & $\overrightarrow{\mathbf{S E}}$ & Mean & $\mathbf{S E}$ & Mean & $\widehat{\mathrm{SE}}$ \\
\hline Men & $8 \cdot 79$ & $(2100)$ & $0.96(230)$ & 8 & 4 & $56 \cdot 4$ & $1 \cdot 5$ & $x \cdot 65$ & 0.21 \\
\hline Women & $6 \cdot 40$ & $(1530)$ & $0.40 \quad(96)$ & 14 & 4 & 45.8 & $1 \cdot 6$ & $1 \cdot 53$ & 0.13 \\
\hline
\end{tabular}

(b) Mortality indices

Crude death rate
Crude birth rate
Population growth
Neonatal mortality
Infant mortality
Mortality o-5 years

Rate (/rooo population)
35
50
15
Rate (/1000 live births)
167
242
403

Nevertheless, once adulthood was reached expectation of life was not low: the chances of a newborn baby achieving this, however, were little more than evens. The high mortality rates also presented in Table $\mathrm{r}(\mathrm{b})$ indicate the situation in Ethiopia in normal times. But it should be noted that they are insufficient to prevent population increase. Indeed, the high birth rates and high death rates are typical of developing countries. To put these results in perspective we have calculated the excess mortality due to underdevelopment by subtracting the UK crude death rate from that in Ethiopia. This gives an estimate of 500000 deaths/year every year, which is about five times the highest estimate of mortality due to famine in 1973. When people die quietly at home instead of in front of television cameras in refugee camps, little international concern is aroused.

This, then, is the background to the events in Wollo in 1973. In the previous year the long rains (June-September) had failed (Ethiopian Meteorological Service, 1974). This trend was apparent throughout eastern Ethiopia but the effects were 
disastrous in Wollo. The situation was exacerbated by widespread failure of the subsequent small rains (February-April) throughout the whole of Ethiopia (Ethiopian Ministry of Agriculture, 1973a). The net result was that the harvest (December) in Wollo was well below average, and there were heavy losses of livestock particularly amongst pastoralists. This fulfilled the expectations of the Ministry of Agriculture, which had warned the Government in November that severe food shortages were likely in the area. By December at least 1000 refugees had reached Addis Ababa and were receiving assistance from the Ethiopian Red Cross. Thus at the beginning of 1973 it was apparent that a serious problem was at hand, but it was not until the end of February that the Food and Agriculture Organization (FAO) issued its Early Warning Food Shortage report (UN Development Programme, 1974) and not until April that the Ethiopian Government requested aid through the international agencies. During these months there had been increased emigration from the worst-affected areas to towns on the main road from Addis Ababa to Asmara. The poorest people came first but small landowners followed, having pawned, sold or simply deserted their holdings to seek work, whilst women and children sought relief. Their number was compounded also by pastoralists from as far as the Danakil desert. Most finished up in understaffed, poorly supplied relief camps set up by roadside town committees and by Community Development Workers. By May increasing numbers of malnourished people arrived and many died. The crisis in numbers and mortality appeared to be reached in August. How many died of starvation and how many because of the poor hygiene of the camps is not clear. It was not until September that the television crews arrived and later that private relief agencies began sending in medical personnel. But by then the crisis was over and the number of refugees had fallen to one-quarter of the August count. The majority, in fact, returned to their villages to attend to their land. The long rains did not fail that year and the crops were generally satisfactory. (According to Eichberger (1966) the average yield of grain from Wollo is $75^{0000} \mathrm{t} /$ year. S. Holmberg (Ethiopian Ministry of Agriculture; personal communication) estimated the yield in the year 1972-3 to be only $120000 \mathrm{t}$, and in $1973^{-4}$ to be as much as $870000 \mathrm{t}$; but aerial photography did indicate some land uncultivated, and the latter may be an over-estimate.) Indeed, the harvest had started when the first grain shipment arrived in an Ethiopian port. During the year the Ethiopian government had distributed $6500 \mathrm{t}$ grain in Wollo, enough for about 65000 people. But by August, the worst month, they had 284000 refugees receiving help (Imperial Ethiopian Government, 1973). It is hardly surprising that there was a high mortality, which was especially marked amongst the very young and the very old.

Commentators in the British media have blamed the Ethiopian government for the inadequacy and delay in grain supplies. Indeed this was a contributory factor to the coup in 1974. However, in retrospect it is clear that the authorities were consulting the international agencies as early as March and had set up a National Drought Relief Committee by April, at which time they had received promises of enough grain to feed 250000 people. Much of the delay must therefore be put down simply to the time it takes to find, organize, ship and distribute food, even 
when the money is available to buy it on world markets. Bearing this in mind, some blame should fall on those responsible for the early warning system, which seems to require action about 5 months before an expected crisis. Alternative tactics to deal with the situation would be for every country to hold a reserve food store to be available to expedite famine relief. It would not need to be large, since famine rarely affects more than one-tenth of a country's population for more than 6 months in a year. But the political problems of buying and free distribution of food are considerable.

It is fair to ask if there was any need to buy foreign grain at all. Ethiopian government statistics show that food production for the whole country was about normal (Tables 2 and 3 ). Thus it should have been possible to buy enough grain on the local markets. This is an important finding. People died in Ethiopia not because of an extreme shortage of food, i.e. famine, but because of an extreme shortage of money, i.e. poverty. One can calculate the amount of money necessary. If one assumes that $\mathrm{I}$ million people needed $500 \mathrm{~g}$ grain/d for half a year $(200 \mathrm{~d})$, the total requirement would be $100000 \mathrm{t}$. If the cost of buying and transporting this grain is $\$ 250$ Ethiopian/t, then at an exchange rate of $\$ 5 / £$ sterling, the total cost would be 65 million, which is less than half the money dissipated by the international charities on medical and other aid. Of course, if one fed only those who were in extreme need as defined by emigration to the roadside camps, the UK charities could have done it alone.

Table 2. Ethiopian crop production for the year 1972, relative to previous average production

\begin{tabular}{lcccc} 
Province & \multicolumn{3}{c}{ Provincial subdistricts (\%) reporting production: } \\
\cline { 2 - 4 } $\begin{array}{c}\text { Above } \\
\text { average }\end{array}$ & Average & $\begin{array}{c}\text { Below } \\
\text { average }\end{array}$ & Poor \\
Wollo & 0 & 10 & 38 & 52 \\
Erigre & 6 & 84 & 2 & 8 \\
Begemder & 4 & 78 & 9 & 9 \\
Gojam & 6 & 84 & 2 & 8 \\
Harer & 14 & 82 & 4 & 0 \\
Arusi & 22 & 39 & 30 & 9 \\
Shoa & 5 & 70 & 15 & 10 \\
Welega & 17 & 54 & 21 & 8 \\
Ilubador & 0 & 86 & 14 & 0 \\
Kaffa & 22 & 64 & 14 & 0 \\
Gemu-Gofa & 33 & 45 & 22 & 0 \\
Sidamo & 6 & 82 & 12 & 0 \\
Bale & 22 & 78 & 0 & 0 \\
All provinces & 82 & 9 & 9 & 0 \\
& 14 & 65 & 14 & 7
\end{tabular}

- From Ethiopian Ministry of Agriculture (1973b).

This figure of $f_{5}$ million is worth bearing in mind when one attempts to estimate the total mortality due to famine. The Ethiopian Nutrition Institute (1974) has put the figure at 100000 , but they have underestimated the normal crude death rate and also the population affected. In their view the affected population was 584000 
Table 3. Total Ethiopian production of various crops for the year 1972, relative to previous average production*

\begin{tabular}{lccc} 
Crop & \multicolumn{3}{c}{$\begin{array}{c}\text { Provincial subdistricts(\%) reporting } \\
\text { production: }\end{array}$} \\
\cline { 2 - 4 } $\begin{array}{c}\text { Above } \\
\text { average }\end{array}$ & Average & $\begin{array}{c}\text { Below } \\
\text { average }\end{array}$ \\
Sorghum & 16 & 51 & 33 \\
Teff (Poa abyssinica Juss.) & 18 & 57 & 25 \\
Barky & 21 & 64 & 15 \\
Wheat & 18 & 60 & 22 \\
Maize & 17 & 55 & 28 \\
All crops & 14 & 65 & 21
\end{tabular}

-From Ethiopian Ministry of Agriculture (1973b).

with a crude death rate of 190 . But their estimation of deaths was based on a biased sample of the worst affected areas. J. F. J. Holt \& J. Seaman (unpublished results) looked at the whole of one agricultural district and found a crude death rate of $8 \mathrm{r}$, and estimated the affected population in Wollo as 800000 . The difference between these values is large and illustrates the lack of definitive data. In neither estimate were there statistical samples which were representative of the whole of Wollo. There is also disagreement as to the normal crude death rate, an essential statistic for calculating the effects of the famine. The Ethiopian Nutrition Institute consider the figure to be as low as 9, which cannot be true, and we found a figure of 35 . Considering all the data, a more realistic appraisal would be total deaths due to famine between 40000 and 80000 , and a possible guess might be 50000 . These people died because the population did not have a reserve of $f_{5} /$ person (the cost of a bottle of malt whisky) to purchase their daily bread the year the rains failed. But if one divides the cost of feeding the province by the excess mortality due to famine, one concludes that the value of human life was froo per head (the cost of a television set). Such are the attributes of poverty. The government did not provide the necessary finance. But again, to be fair, the mean individual income in Ethiopia

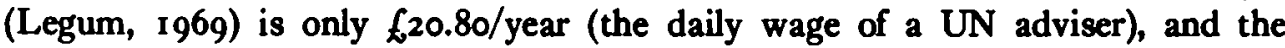
national revenue (Whitaker's Almanac, 1965) of $\$ 29.1 \mathrm{million} / \mathrm{year}$ (the cost of building $40 \mathrm{~km}$ of motorway in the UK) was inadequate to buy and distribute enough grain. Such are the attributes of national poverty.

Thus it is all too easy to ascribe the famine in Wollo province to long-term climatic changes or even to an unusual failure of the rains. Although it was the worst in recent memory, it is by no means the only natural disaster on record in Ethiopia. For instance, using contemporary chronicles and the writings of foreign travellers, Pankhurst (1966) has found at least twenty-six major famines occurring between $154^{\circ}$ and $1800 \mathrm{AD}$. In these, pests featured more than drought as the immediate cause. The great famine of $1888-92$, possibly the worst on record, included elements of drought, locust and a devastating plague of rinderpest (cattle plague) said to have been caused by an Italian importation of some infected cattle. Any and all of these factors are sufficient to cause a crisis in the rural economy and the sad fact is that the subsistence farmer has insufficient reserves of capital to 
withstand the temporary set-back they cause. In Ethiopia, the supply of food was more than sufficient to meet the economic demand: the trouble was that the economic demand did not equal the physiological need. Increased aid to the subsistence farmer should be directed to rectify this position. It is not just a matter of increasing food production, although this is desirable if only to improve the quality of life.

There is a curious conflict between those who claim that world population is increasing too fast, and those who say there is a widespread shortage of food. Surely it is a biological paradox for both to exist together. Notwithstanding famine, plagues and feudalism, the Ethiopian peasant has survived and multiplied these past 1000 years. However, for man to survive on very low food intakes exposes him to the vagaries of climate and pestilence which produce the lean and hungry years. More important than increasing food production is the need to increase rural wealth to cushion the worst effects of these natural disasters. It is apparent that quite small sums of cash can enable the rural population to buy their way out of difficulties. Overseas food aid to Ethiopia in 1973 failed dismally, largely because it arrived too late. The distribution of stocks of grain by the Ethiopian government only partially alleviated the situation because it was too meagre. Thus, in the light of these experiences, neither the early warning system of FAO nor the system of local grain stockage for free distribution allows us to hope that another drought would not lead to similar heavy mortality. The most sensible method of preventing famine is to provide the peasant with the means to save himself. This would require an extent of development that might also reduce the annual toll of 500000 deaths that occur in Ethiopia as a result of chronic undernutrition and lack of public health engineering, and which pass almost unnoticed.

The studies reported in Table I formed part of the Ethiopian Applied Nutrition Programme, Adi Arcai, 1970-73.

\section{REF ERENCES}

Eichberger, W. G. (1966). Food Production and Utilization in Ethiopia. Addis Ababa: USAID. Ethiopian Meteorological Service (1974). Brief Provisional Review of the Recent Drought in Ethiopia. Addis Ababa: Imperial Ethiopian Government.

Ethiopian Ministry of Agriculture (1973a) Effects of the Belg Rain Failure. Addis Ababa: Imperial Ethiopian Government.

Ethiopian Ministry of Agriculture (1973b). Final Report of Crop Condition Survey for the 1972-3 Harvest. Addis Ababa: Imperial Ethiopian Government.

Ethiopian Nutrition Institute (1974). Profile of Wollo under Famine. Addis Ababa: Ethiopian Nutrition Institute.

Imperial Ethiopian Government (1973). The Drought Problem in Ethiopia. Addis Ababa: Imperial Ethiopian Government.

Legum, C. (1969). Africa Handbook. London: Penguin Books.

Pankhurst, R. (1966). J. Ethiopian Stud. 4, 2.

Rivers, J. P. W., Seaman, J. \& Holt, J. (1974). Lancet ii, 947.

UN Development Programme (1974). Second Report on the Drought in Ethiopia. Addis Ababa: UN Development Programme.

Whitaker's Almanac (1965). 97th ed. London: Whitaker.

Printed in Great Britain 